\title{
COMMENTARY
}

\section{Calcium confusion - is the variability in calcium response by Sertoli cells to specific hormones meaningful or simply redundant?}

\author{
F F G Rommerts ${ }^{1}$, F M Lyng ${ }^{2}$, E von Ledebur ${ }^{3}$, L Quinlan ${ }^{4}$, \\ G R Jones ${ }^{5}$, J B Warchol ${ }^{6}$, M Stefanini ${ }^{7}$, N Ravindranath ${ }^{8}$ and \\ M Joffre ${ }^{9}$ \\ ${ }^{1}$ Department of Endocrinology \& Reproduction, Erasmus University Rotterdam, The Netherlands, \\ ${ }^{2}$ Radiation Science Centre, Dublin Institute of Technology, Dublin, Ireland \\ ${ }^{3}$ Laboratório de Endocrinologia Experimental, UFRGS, Porto Alegre, Brazil \\ ${ }^{4}$ Physiology Department, National University of Ireland, Galway, Ireland \\ ${ }^{5}$ Synchrotron Radiation Department, CLRC Daresbury Laboratory, Warrington, UK \\ ${ }^{6}$ Department of Radiobiology and Cell Biology, School of Medicine, Poznan, Poland \\ ${ }^{7}$ Department of Histology and Medical Embryology, University 'La Sapienza' of Rome, Italy \\ ${ }^{8}$ Department of Cell Biology, Georgetown University Medical Centre, Washington, USA \\ ${ }^{9}$ Laboratoires de Physiologie des Regulations Cellulaire, UFR Sciences, Poitiers-Cedex, France \\ (Requests for offprints should be addressed to F F G Rommerts, Department of Endocrinology and Reproduction, Erasmus University Rotterdam, \\ PO Box 1738, 3000 DR Rotterdam, The Netherlands; Email: rommerts@endov.fgg.eur.nl)
}

\begin{abstract}
When results of more than ten different studies on hormone-induced calcium signals in Sertoli cells are taken together, a wide variety of responses emerges. The reported changes range from increased concentrations, via no response at all, to decreased calcium concentrations. Minor variations in cell isolation techniques, culture conditions, or techniques for measuring the intracellular calcium could explain some of these differences. However, erratic variations in response are also observed within research groups under very similar experimental conditions. Such 'negative' findings are mainly reported orally and do not further penetrate the scientific community. As hormone-dependent calcium responses evidently may depend very much on the context of the cells, calcium
\end{abstract}

transients would appear to be unreliable bioassay principles with which to detect the primary actions of FSH and effectors such as androgens on Sertoli cells. A more important biological question is whether these sometimes opposed calcium transients are connected with a particular cellular response. To date there is no evidence for such a tight coupling in Sertoli cells, implying that, at least under in vitro conditions, calcium signals might even be redundant altogether. Such calcium variability is probably not unique to Sertoli cells, and the aim of this commentary is to promote an open debate that may help to transform the current state of 'calcium confusion' into a better understanding of the intracellular calcium language.

Journal of Endocrinology (2000) 167, 1-5

\section{Introduction}

Measuring the concentration of molecules in biological fluids using bioassays has been and continues to be a difficult task. Although the quality of the cells and the hormone preparations, antibodies, culture media, instrumentation and analytical techniques have improved vastly, discussions on the best conditions for bioassays have not stopped. On the one hand responsive cells have the advantage that they can amplify weak hormonal signals and generate a measurable response, whereas on the other hand, the same cells can amplify non-specific or unknown specific signals and so mask the specific hormone response. Even the response of well-characterised cell-lines in chemically defined media is not always consistent, because properties of the cells can be modified during the culture period. Thus responses of cells may vary slightly between laboratories and even within one laboratory, when cells are used during different periods. This heterogeneity of responses between different experiments has been accepted as an inherent property of biological systems. However, heterogeneity in responses also seems 
to occur within a population of identical cells, even when influences of the cell cycle have been minimised. From studying hormone responses in terms of changes in intracellular calcium in individual cells, it has become apparent that not all cells respond at the same time or in the same fashion. The origin and the implications of this heterogeneity in calcium signalling, which acts probably as the most universal second messenger system (Berridge et al. 1998), is difficult to understand. With our knowledge of paracrine and autocrine regulation of cell function, we can explain why density or position of individual cells in a population could have an influence on cellular properties. Yet it is difficult to explain the observed diversity of responses in apparently similar cells in the same environment. This could arise from the non-linear and chaotic properties of complex biological systems that operate inside the cell (Coffey 1998). It is therefore possibly understandable that similar cells will not always give identical calcium responses when exposed to specific hormones. However, recent observations with calcium responses in primary non-dividing rat Sertoli cells, and in cells from the human prostatic cell line LNCaP, appear to go beyond this generally accepted variability.

\section{Variability in calcium responses}

Responses of intracellular calcium in Sertoli cells (and also in $\mathrm{LNCaP}$ cells) after addition of protein or steroid hormones are presented in Table 1 . The data show that the responses of cells under very similar in vitro conditions can be very different, not only in regard to the kinetics or specificity of the response, but even between being stimulatory or inhibitory.

There are several technical possibilities to explain such variations. Differences in labelling or sub-cellular distribution of the calcium-sensitive fluorescent dye, backtransport or leakage of the dye after stimulation (especially in freshly isolated cells) and photobleaching could mask the authentic calcium response. However, in several instances cells did not show a calcium response to the specific hormone applied whereas, in the same cells, calcium responses could be shown after addition of potassium, foetal calf serum or ATP (D'Agostino et al. 1993, Lalevee et al. 1999). Thus technical problems seem to be of less importance and the variations in hormone-dependent calcium responses appear to depend more on the properties of particular receptors or cellular set points.

The variability does not appear to have anything to do with expression of specific receptors as, for LNCaP cells for example, there is always a typical bell-shaped growth response to cognate effectors. Also, the Sertoli cells always respond to FSH with increased cAMP production and show characteristic changes in cell shape. Remarkable is the apparent age-dependent dissociation between the highly reproducible cAMP response and the variable calcium response. Authors claim that at least part of the calcium responses in 21-day old rats are mediated via cAMP (Gorczynska et al. 1994), but this is less in 9-day (Sharma et al. 1994), and does not occur in 13-day old rats (Grasso \& Reichert 1990). Very recently it was suggested that the calcium response is only mediated by a particular, truncated FSH receptor, and not by the regular 7-transmembrane form (Touyz et al. 2000). On the other hand, the calcium response in a homogenous population may depend completely on contact with matrix components or interactions with homotypic cells (Ravindranath et al. 1996, Taranta et al. 2000). Variability in the kinetics, the dose-response characteristics and the subcellular localisation of calcium responses in single cells has also been reported for smooth muscle and endothelial cells (Wehling et al. 1994). Thus cells may show much more individual behaviour than we currently assume.

Although some variations in calcium responses can be understood, it is very difficult to explain how calcium responses can go in opposite directions under comparable in vitro conditions. The suggestion has been made that the basal calcium concentration could be an important factor for the direction of the response after hormonal stimulation (Lalevee et al. 1999), but it is hard to understand why basal calcium concentrations vary between similar experiments within a single laboratory. We have made many attempts to understand the origin of these calcium variations by making numerous alterations to the experimental conditions. However, despite these many efforts, the problems remain. In the original publications (see Table 1), details can be found about techniques, experimental conditions and results, in addition to attempts to understand the apparent discrepancies in experimental findings. However, all these published and unpublished observations, together with the derived (more verbal than printed) discussions do not give rise to concurrent views, but rather create confusion, with some investigators even describing their research as 'living in the Sertoli-cell-Hell'. Negative or unexpected observations in individual experiments do not necessarily indicate poorly executed experiments or a faulty experimental design that should be ignored. On the contrary, most of them may reflect genuine cellular properties that demand attention. However, because negative or unexplainable findings are difficult to publish, the current literature does not represent a true reflection of the 'calcium-reality'.

\section{Consequences of variability in calcium responses}

If it is true that the context or origin of the cells can sometimes contribute more to the calcium response than the hormone of interest, then we must ask the question 'are bioassays using calcium responses reliable?' For FSH action, this is less of a problem, because the receptor has been cloned and many observations from in vivo and in vitro 
Table 1 Calcium responses in Sertoli cells and LNCaP cells after addition of protein and steroid hormones*

\begin{tabular}{|c|c|c|c|c|c|}
\hline & Hormone & Age of rat (days) & Cellular calcium response & Remarks & Reference \\
\hline Sertoli & FSH & 21 & $\begin{array}{l}3 \text {-fold stimulation } \\
\text { during } 3 \mathrm{~min}\end{array}$ & $\begin{array}{l}\text { Freshly isolated } \\
\text { cell aggregrates }\end{array}$ & Gorczynska \& Handelsman 1991 \\
\hline Sertoli & FSH & 9 & $\begin{array}{l}\text { 2-fold stimulation } \\
\text { during } 2 \mathrm{~min}\end{array}$ & $\begin{array}{l}3 \text { days culture } \\
\text { all or nothing } \\
\text { responses in } \\
\text { individual cells }\end{array}$ & Sharma et al. 1994 \\
\hline Sertoli & FSH & 10 & $\begin{array}{l}2-3 \text {-fold inhibition } \\
\text { within seconds }\end{array}$ & 4 days culture & Ravindranath et al. 1996 \\
\hline Sertoli & FSH & 13 & $\begin{array}{l}\text { No response }(20 \%) \\
\text { Inhibition during } 6 \text { min }(20 \%) \\
\text { Rapid stimulation (few seconds), } \\
\text { later, slow inhibition }(60 \%) \\
\text { Stimulation }(100 \%) \text { within a } \\
\text { few seconds }\end{array}$ & 4 days culture & Lalevee et al. 1999 \\
\hline Sertoli & $\begin{array}{l}\text { FSH } \\
\text { EGF }\end{array}$ & $\begin{array}{l}21- \\
25\end{array}$ & $\begin{array}{l}\text { 4-fold transient stimulation } \\
\text { followed by plateau at } \\
\text { lower level }\end{array}$ & 4 days culture & Lyng et al. 2000 \\
\hline LNCaP & Androgens & - & $\begin{array}{l}3 \text {-fold stimulation } \\
\text { within } 1 \text { min }\end{array}$ & - & Steinsapir et al. 1991 \\
\hline Sertoli & Androgens & 21 & $\begin{array}{l}\text { 2-fold stimulation } \\
\text { during } 3 \mathrm{~min}\end{array}$ & $\begin{array}{l}\text { Freshly isolated } \\
\text { cell aggregates }\end{array}$ & Gorczynska \& Handelsman 1991 \\
\hline LNCaP & $\begin{array}{l}\text { Androgens } \\
\text { Oestradiol }\end{array}$ & - & $\begin{array}{l}\text { 4-fold stimulation } \\
\text { during } 6 \text { min } \\
\text { 3-fold stimulation } \\
\text { during } 6 \text { min }\end{array}$ & $\begin{array}{l}\text { Inhibited by } \\
\text { anti-androgens } \\
\text { Not inhibited by } \\
\text { anti-androgens }\end{array}$ & Audy et al. 1996 \\
\hline $\begin{array}{l}\text { LNCaP } \\
\text { and Sertoli }\end{array}$ & Androgens & - & $\begin{array}{l}\text { Low doses: } \\
\text { rapid transient response } \\
\text { High doses: } 5 \text {-fold stimulation } \\
\text { with plateau after } 2 \text { min } \\
\text { No response }\end{array}$ & $\begin{array}{l}\text { Inhibited by } \\
\text { anti-androgens }\end{array}$ & Lyng et al. 2000 \\
\hline
\end{tabular}

*Summary of effects of protein and steroid hormones on intracellular calcium measured with ${ }^{45}$ calcium (Grasso \& Reichert 1990) or with calcium sensitive fluorescent dyes (all except Grasso \& Reichert 1990) in non-dividing primary rat Steroli cells, or in cells from the human prostatic cell line LNCaP. 
studies have shown the importance of this receptor for regulation of the function of the Sertoli cell, acting mainly via cAMP. The situation is completely different for complementary actions of androgens, possibly acting at the plasma membrane. Non-genomic actions of steroids have often been identified by measuring rapid calcium fluxes (see review by Christ et al. 1999). If steroid-activated membrane receptors on other cells, and other steroids besides androgens, all behave in a manner similar to what we observe with Sertoli and LNCaP cells, then it will be very difficult to prove the existence of membrane steroid receptors using changes in calcium concentrations as the response parameter. Other approaches such as binding studies and cloning strategies have also not been very successful. Thus the position of separate steroid membrane receptors in general is not very strong. This uncertainty may have contributed to the title of the previously cited review 'Nongenomic steroid actions: fact or fantasy?' (Christ et al. 1999). As negative findings on calcium responses have less weight than positive findings, the overall balance of published experimental evidence still supports the existence of separate membrane receptors for steroids. Clearly, other reliable indices of hormone action are required before these alternative receptor systems can be firmly accepted as important entities. It would be much more convincing if another specific biological response, rather than calcium, could be found that is triggered by these membrane receptors. However, most biological responses appear to develop slowly, and signals from slowly acting nuclear receptors may then become integrated into the same signal transduction pathway during the generation of the response to the membrane receptor. As specific ligands for separate activation of the membrane and nuclear receptors are often not available, and as the majority of the cells contain nuclear steroid receptors, it becomes very difficult to demonstrate a specific activation of a putative steroid membrane receptor, if we cannot accept rapid calcium transients as a reliable tool for identification of alternative steroid action.

Accepting for the moment that calcium transients can go in opposite directions, even when in vitro conditions are similar, the question then arises whether the opposed calcium transients are connected with a particular cellular response. From the limited number of experiments discussed here, we have found no evidence for such a connection, and we can only conclude that opposed calcium signals do not necessarily generate different biological responses. This speculative conclusion is clearly in contrast with the current view that even minor variations in calcium in space or time are important in specific signal transduction events (Berridge et al. 1998). If the variability in intracellular calcium concentrations occurs without measurable biological effects, then does this mean that calcium signals in specific cell types are redundant in a fashion analogous to certain genes ablated in transgenic animals?
Notwithstanding the fact that these observations are made with cells in culture and may not apply under physiological conditions when cells are organised in a tissue environment, most of our knowledge about hormone actions and calcium regulation comes from studies with isolated cells, especially after specific genetic manipulations have been conducted.

\section{Conclusion}

Current studies on calcium responses to specific effectors in cultured Sertoli cells, despite careful experimentation, are highly contradictory. We have to find a way to characterise the origin and significance of this variation in calcium signalling. One way might be to use a single-cell approach, correlating calcium and cAMP responses, measured simultaneously with different fluorescent probes, in the same cell. Similarly, other parameters, e.g. pH, potassium concentration, oxidative activity, cytoskeleton or enzymatic activities could also be analysed at the single cell level. As the number of fluorescent probes available is increasing steadily, as also is the quality of instrumentation, it should eventually be possible to identify patterns of calcium individuality after exposure to hormones, and thus finally to throw some light onto the current confusing situation.

\section{References}

Audy MC, Vacher P \& Dufy B 1996 17 $\beta$-Estradiol stimulates a rapid $\mathrm{Ca}^{2+}$ influx in LNCaP human prostate cancer cells. European Journal of Endocrinology 135 367-373.

Berridge MJ, Bootman MD \& Lipp P 1998 Calcium - a life and death signal. Nature 395 645-648.

Christ M, Haseroth K, Falkenstein E \& Wehling M 1999 Nongenomic steroid actions: fact or fantasy? Vitamins and Hormones 57 325-373.

Coffey DS 1998 Self-organisation, complexity and chaos: the new biology for medicine. Nature Medicine 4 882-885.

D’Agostino A, Mene P \& Stefanini M 1993 Voltage-gated calcium channels in rat Sertoli cells. Biology of Reproduction 46 414-418.

Gorczynska E, Handelsman DJ 1991 The role of calcium in follicle-stimulating hormone signal transduction in Sertoli cells. Journal of Biological Chemistry 266 23739-23744.

Gorczynska E \& Handelsman DJ 1995 Androgens rapidly increase the cytosolic calcium concentration in Sertoli cells. Endocrinology 136 2052-2059.

Gorczynska E, Spaliviero J \& Handelsman DJ 1994 The relationship between $3^{\prime} 5^{\prime}$-cyclic adenosine monophosphate and calcium in mediating follicle stimulating hormone signal transduction in Sertoli cells. Endocrinology 134 293-300.

Grasso P \& Reichert LE 1990 Follicle-stimulating hormone receptormediated uptake of ${ }^{45}$ calcium by cultured rat Sertoli cells does not require activation of cholera toxin- or pertussis toxin-sensitive guanine nucleotide binding proteins or adenylate cyclase. Endocrinology 127 949-956.

Lalevee N, Rogier C, Becq F \& Joffre M 1999 Acute effects of adenosine triphosphates, cyclic 3', 5'-adenosine monophosphates and follicle-stimulating hormone on cytosolic calcium level in 
cultured immature rat Sertoli cells. Biology of Reproduction 61 343-352.

Lyng FM, Jones GR \& Rommerts FFG 2000 Rapid androgen actions on calcium signaling in rat Sertoli cells, and two human prostatic cell lines: similar biphasic responses between $1 \mathrm{pM}$ and $100 \mathrm{nM}$. Biology of Reproduction 63 736-747.

Ravindranath N, Papadopoulos V, Brooker G \& Dym M 1996 Rat Sertoli calcium response to basement membrane and follicle stimulating hormone. Biology of Reproduction 54 130-137.

Sharma OP, Flores JA, Leong DA \& Veldhuis JD 1994 Cellular basis for follicle stimulating hormone stimulated calcium signaling in single rat Sertoli cells: possible dissociation from effects of adenosine 3'5'-monophosphate. Endocrinology 134 1915-1923.

Steinsapir J, Socci R \& Reinach P 1991 Effects of androgen on intercellular calcium of LNCaP cells. Biochemical and Biophysical Research Communications 179 90-96.
Taranta A, Teti A, Stefanini M \& D'Agostino A 2000 Immediate cell signal induced by laminin in rat Sertoli cells. Matrix Biology 19 $11-18$.

Touyz RM, Jiang L \& Sairam MR 2000 Follicle-stimulating hormone mediated calcium signaling by the alternatively spliced growth factor type I receptor. Biology of Reproduction 62 1067-1074.

Wehling M, Ulsenheimer A, Schneider M, Neylon C \& Christ M 1994 Rapid effects of aldosterone on free intracellular calcium in vascular smooth muscle and endothelial cells: subcellular localization of calcium elevations by single cell imaging. Biochemical and Biophysical Research Communications 204 475-481.

Received 28 April 2000

Accepted 15 June 2000 